UDC 676.038.2

A. Ostapenko, M. Gomelya, O. Movchaniuk, I. Trembus

\title{
REINFORCING A TESTLINER WITH SUPPORTING CHEMICAL MATERIALS
}

\author{
National Technical University of Ukraine «Igor Sikorsky Kyiv Polytechnic Institute», Kyiv, Ukraine
}

\begin{abstract}
The simulation of the chemical interaction of amphoteric polymer resin with sucrose having hydroxyl groups that are similar to cellulose were carried out using ${ }^{13} \mathrm{C}$ NMR spectroscopy. The transformation of azetidine groups of amphoteric polymer resin proved to result in the formation of covalent chemical bonds between the resin molecules and the hydroxyl groups of sucrose. The mechanism of the interaction of amphoteric polymer resin with cellulose macromolecules was confirmed. The effect of the consumption of amphoteric polymer resin on the physical-mechanical properties of a testliner with different composition was investigated. It was determined that there is a significant increase in the cardboard indices of all studied compositions with an increase in the consumption of resin from 1 to $4 \mathrm{~kg}$ per ton. A further increase in the consumption of resin does not practically change the strength of the cardboard, and hence is economically unreasonable. It was found that a greater efficiency of the use of amphoteric polymer resin is achieved when the content of a short-fiber fraction cardboard in the composition grows. It was shown that the consumption of resin of $4 \mathrm{~kg}$ per ton and the use of $30 \%$ short-fiber waste paper in the composition ensure an increase in the burst resistance and the destructive force during the compression of the ring by $23 \%$ and $18 \%$, respectively; these parameters being the main indicators of mechanical strength of the cardboard. This, in turn, will reduce the cost of a testliner. The samples of a testliner with different composition were examined by the SEM method, the samples were fabricated without and with the addition of amphoteric polymer resin. The formation of a dense structure of a cardboard in the case of the use of resin and short-fiber waste paper was shown, this led to an increase in the strength of cardboard.
\end{abstract}

Keywords: amphoteric polymer resin, azetidine groups, sucrose, cellulose, ${ }^{13} \mathrm{C}$ NMR spectroscopy, wastepaper, testliner, physical-mechanical properties.

DOI: $10.32434 / 0321-4095-2019-127-6-149-156$

\section{Introduction}

The utilization of the waste paper is a complex and problematic task for enterprises producing various types of paper and cardboard. The main reason for inhibiting the growth of volumes of waste paper consumption in the production of cardboard and paper products is the deterioration of paper making properties of secondary fibers with an increase in the number of recycling cycles [1,2]. Because of the repeated consumption of more than $50 \%$ of waste paper that is used in the production of paper and cardboard, it has low papermaking properties, which is accompanied by an increase in the ash content and a significant content of a fine-fraction $[3,4]$. The reduction of papermaking properties of secondary fibers during a repeated use is due to irreversible changes in the structure of cell walls of fibers that occur under the influence of grinding processes of fibrous semi-finished products, gluing and drying of a paper cloth $[5,6]$. The influence of these technological processes leads to the shortening and hornification of fibers, a sharp decrease in their flexibility, plasticity, substantial loss of fiber's ability to hydrate (swelling) and, consequently, to weaken the inter-fiber bonds in a sheet of paper [7].

One of the effective ways to increase the strength of cardboard and paper products from waste paper is the addition of chemical auxiliaries to a fibrous suspension. Starches, especially cationmodified, carboxymethyl cellulose, liquid glass and synthetic polymers, such as cationic polyacrylamides and high-molecular polyvinyl amine [8-10], are used for this purpose.

The amphoteric polymer resins (APS) produced 
by the reaction of polymerization of diaminodietilamine with epichlorohydrin followed by the treatment with distillation of water under vacuum at the temperature higher than $200^{\circ} \mathrm{C}$ [11] were used in the paper and cardboard technology mainly to give them moisture resistance. However, ref. [12] reported the effect of the APS on the growth of the strength of a paper made from the recycled paper. In addition, it was stated that the use of the APS in the composition can significantly intensify the process of dehydration of the fibrous mass on the grid of the papermaking machine and reduce the loss of the fine fiber with the tray water. This ultimately reduces both the amount of the solid waste and the consumption of natural water. It is also important that the APS are environmentally friendly.

The purpose of this work is to evaluate the degree of the transformation of azetidine groups of amphoteric polymer resins in the course of the interaction with reactive methylol- $-\mathrm{CH}_{2}-\mathrm{OH}$ organic compounds by using ${ }^{13} \mathrm{C}$ NMR spectroscopy method and to establish the effect of the resins on the quality of a testliner with a high content of a short-fiber waste paper. The interaction of the APS with polyalcohols was described elsewhere [13].

\section{Experimental}

The APS UltraRes 200 was used as an auxiliary chemical, which better contributes to the increase of physical-mechanical parameters of paper from waste paper [12].

The ${ }^{13} \mathrm{C}$ NMR spectra of product solutions of the APS UltraRes 200 and sucrose were recorded using the Bruker's AVANCE-400 spectrometer at the frequency of $100.613 \mathrm{MHz}$. The magnitudes of chemical shifts of the ${ }^{13} \mathrm{C}$ NMR signals have been determined with respect to the signals of tetramethylsilane [14]. The interval between pulses was $4 \mathrm{~s}$ with a total accumulation of 4000 . The Fourier transforms were performed with the simultaneous exponential weighing of the free induction recession with a constant equivalent to the expansion of the lines of $10 \mathrm{~Hz}$.

In order to evaluate the effectiveness of the influence of APS on the physical and mechanical parameters of a cardboard, a series of samples of the cardboard $\left(175 \pm 5 \mathrm{~g} / \mathrm{m}^{2}\right)$ of different composition was manufactured using the group 1 of waste paper (code 1.05.01 corrugated cardboard) and the group 2 (code 2.01.00 newspaper) according to EN 643 «Paper and board - the European list of standard grades of paper and board for recycling» taken in the ratios of 100:0, 90:10, 80:20, 70:30, and 0:100.

The physical and mechanical characteristics of the cardboard samples have been determined

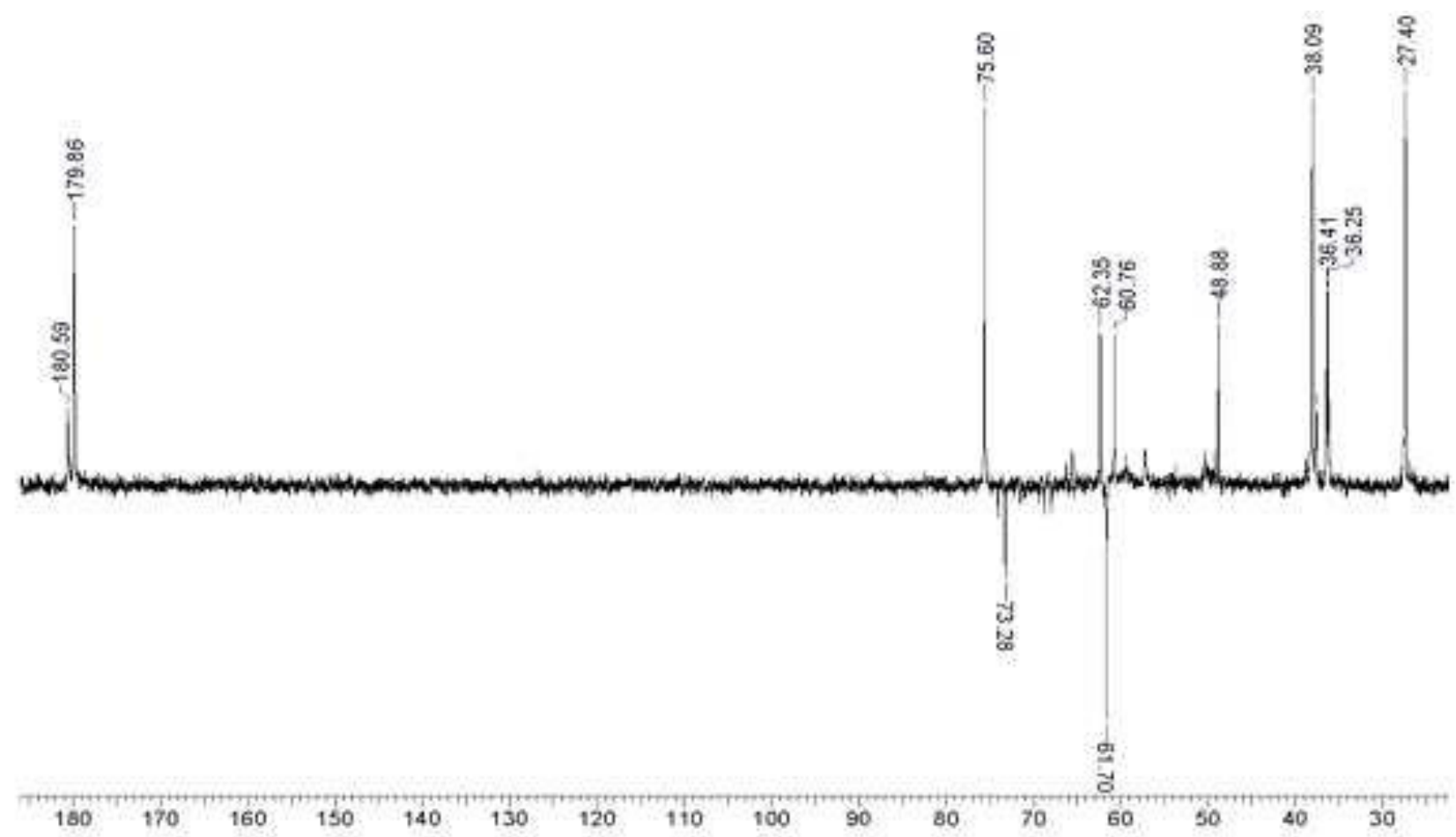

Chemical shift, ppm

Fig. $1 .{ }^{13} \mathrm{C}$ NMR spectrum of the APS UltraRes 200 water solution 


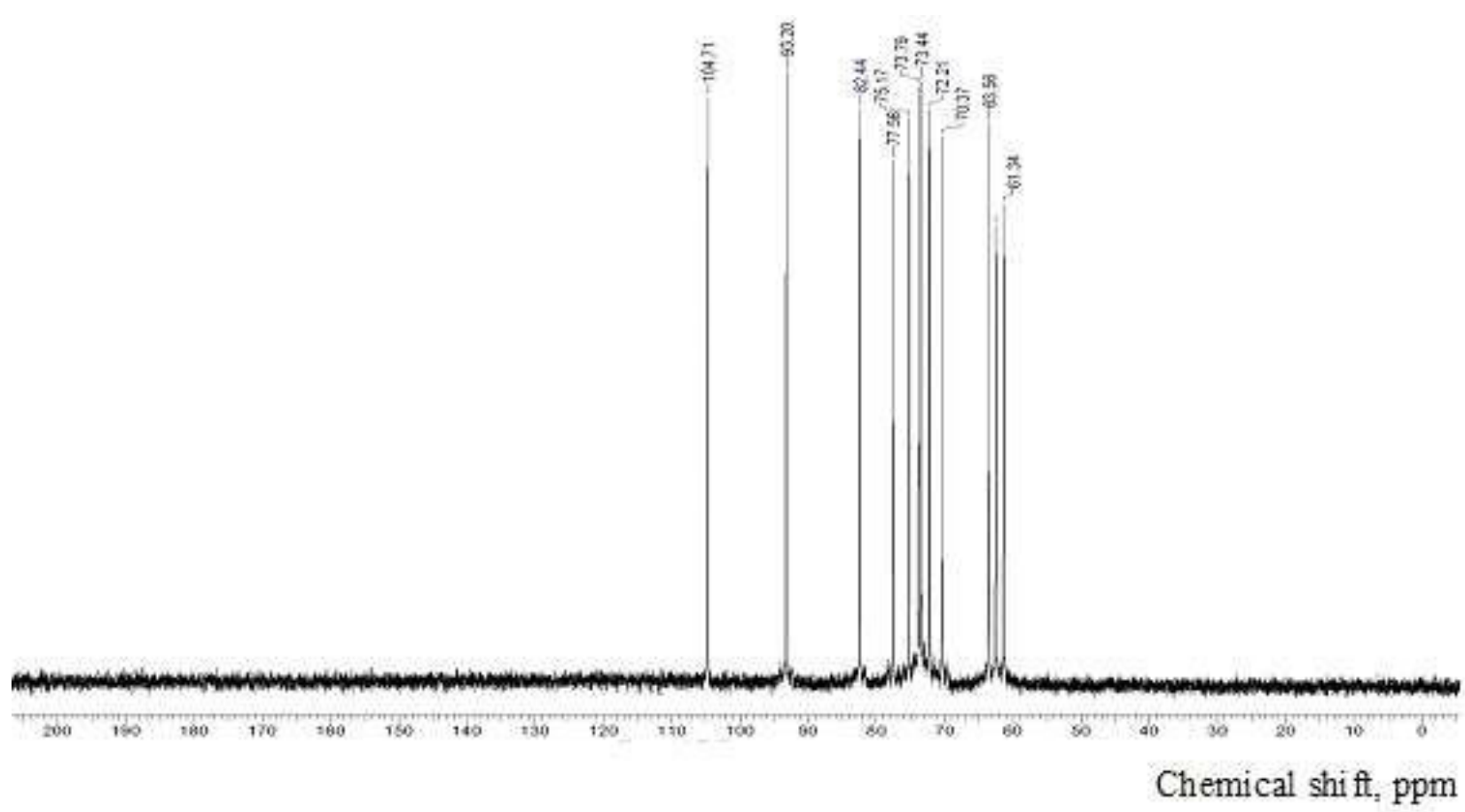

Fig. $2 .{ }^{13} \mathrm{C}$ NMR spectrum of the solution of sucrose

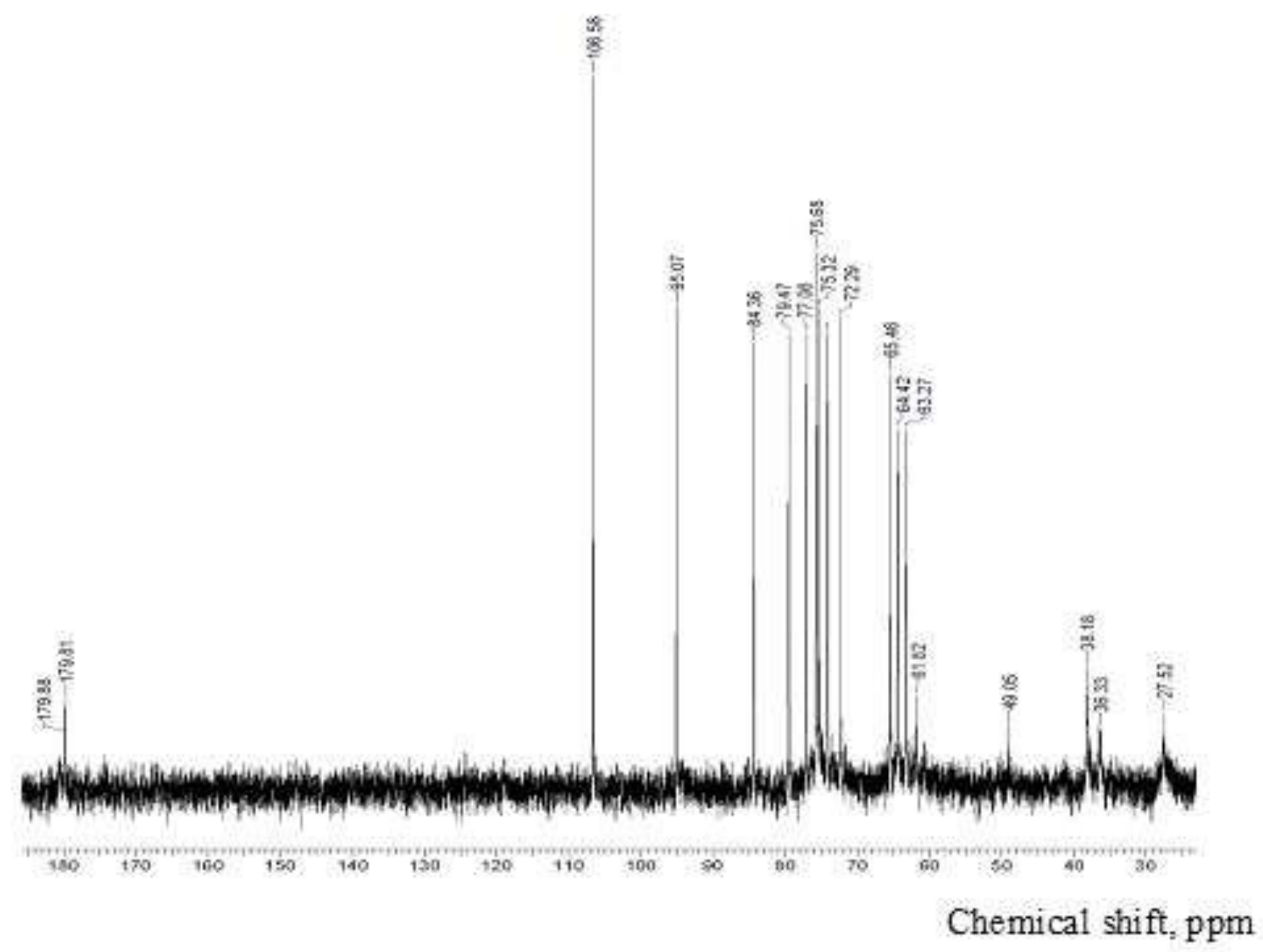

Fig. 3. ${ }^{13} \mathrm{C}$ NMR spectrum of the system sucrose-UltraRes $200-\mathrm{H}_{2} \mathrm{O}$ 
according to the following standard methods: the rigidity determination was performed using the ring compression method and the burst resistance (ISO 12192 and ISO 2759, respectively).

The microphotographs of the cardboard samples were obtained using an electronic raster microscope REM-106I equipped with the system of energydispersive micro-analysis in a high vacuum mode of $4 \mathrm{~nm}$. The voltage at the cathode was $30 \mathrm{kV}$.

\section{Results and discussion}

Due to the insolubility of cellulose in water, a sucrose substance, which is readily soluble in water, was used to study the processes of the interaction of the APS with cellulose at a molecular level. Sucrose, similar to cellulose, has glucosidic cycles and hydroxyl groups; therefore it can be considered as a model substance. To increase the concentration of the APS, the model substance was introduced into aqueous solution of the APS UltraRes 200, which allowed simulating the interaction of the APS with cellulose.

Figures $1-3$ show the ${ }^{13} \mathrm{C}$ NMR spectra of aqueous solutions of both the individual APS UltraRes 200 substances and sucrose and the systems sucrose-UltraRes $200-\mathrm{H}_{2} \mathrm{O}$.

As can be seen from Figs. 1-3, the difference between the chemical shifts of solutions of individual substances under investigation and their mixture is about $1.5-2.0 \mathrm{ppm}$. The chemical shifts of functional groups that are active in the formation of the intermolecular hydrogen bonds for carbon atoms in a solution of sucrose are $104.71 \mathrm{ppm} ; 93.20 \mathrm{ppm}$ and $82.24 \mathrm{ppm}$, whereas these chemical shifts for the system «sucrose-UltraRes $200-\mathrm{H}_{2} \mathrm{O}$ are 106.58 ppm; $95.07 \mathrm{ppm}$ and $84.36 \mathrm{ppm}$, respectively. The magnitude of the changes in the values of chemical shifts reveals the redistribution of electron density in hydrocarbon chains, which, depending on their structural and functional characteristics, affects the time of NMR-relaxation of the corresponding carbon atoms. The reduction of the relaxation time leads to an increase in the width of the resonance signals and a decrease in the amplitude of the signals for the approximate preservation of the integral intensity of the characteristic sucrose lines. This indicates the preservation of the structure of sucrose in the process of the interaction with the APS.

The interaction of azetidine cycles of the APS with sucrose results in disappearance of signals in the region of 75.6 and $61.7 \mathrm{ppm}$, which corresponds to the carbon atoms in a four-member cycles. Obviously, the interaction follows Scheme 1.

The effect of the APS UltraRes 200 on the main indices of mechanical strength of a testliner for a different composition is shown in Fig. 4.

The addition of resin in the amount of $1 \mathrm{~kg}$ per ton to $4 \mathrm{~kg}$ per ton leads to an improvement in the strength of the cardboard samples of all studied compositions. Thus, the burst strength and the rate of breaking force by the ring compression increase by $6-23 \%$ and $7-26 \%$, respectively. A further increase in the consumption does not practically change the strength of the cardboard, and therefore it is economically inexpedient.

It should be noted that the obtained physicalmechanical parameters show that the samples of a cardboard, made only from waste paper of group 2, are considerably inferior to samples that are entirely made from waste paper of group 1.

The obtained results indicate that a partial replacement (up to $30 \%$ ) of the more expensive waste paper of group 1 in a fibrous composition by a short fibereboard waste paper of group 2 reduces the cost of a cardboard.

It is known that a short fiber fraction has a highly developed specific surface of the fiber, which leads to an increase in hydrogen bonds between the hydroxyl groups of cellulose and the APS UltraRes 200 , thereby contributing to an increase in the strength of the cardboard. The mechanism of the interaction of the APS UltraRes 200 and hydroxyl groups of cellulose are shown in Scheme 2.

In order to establish structural changes of testliner samples of different composition without and with the addition of the APS UltraRes 200 at its consumption of $4 \mathrm{~kg}$ per ton of products, the microscopic studies were carried out. The

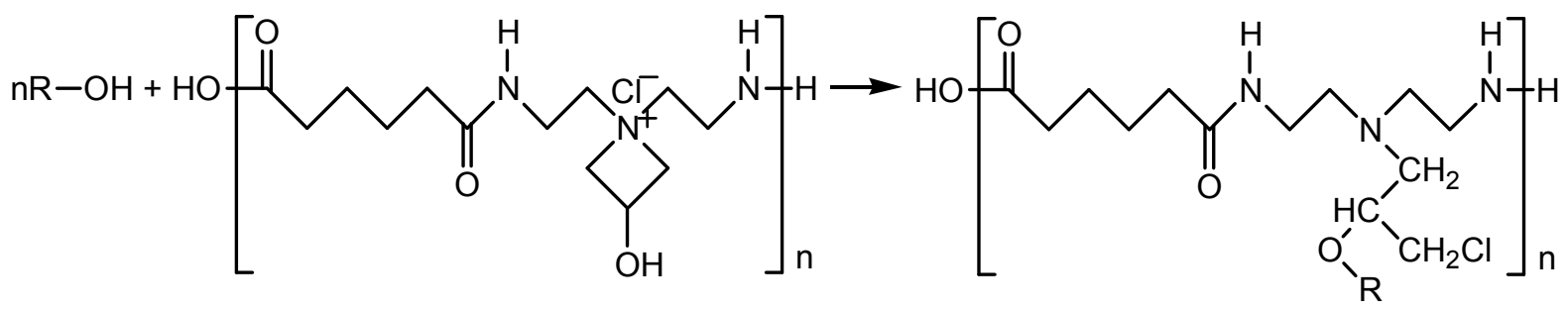

where $\mathrm{R}$ is $\mathrm{C}_{12} \mathrm{H}_{21} \mathrm{O}_{10}$ 

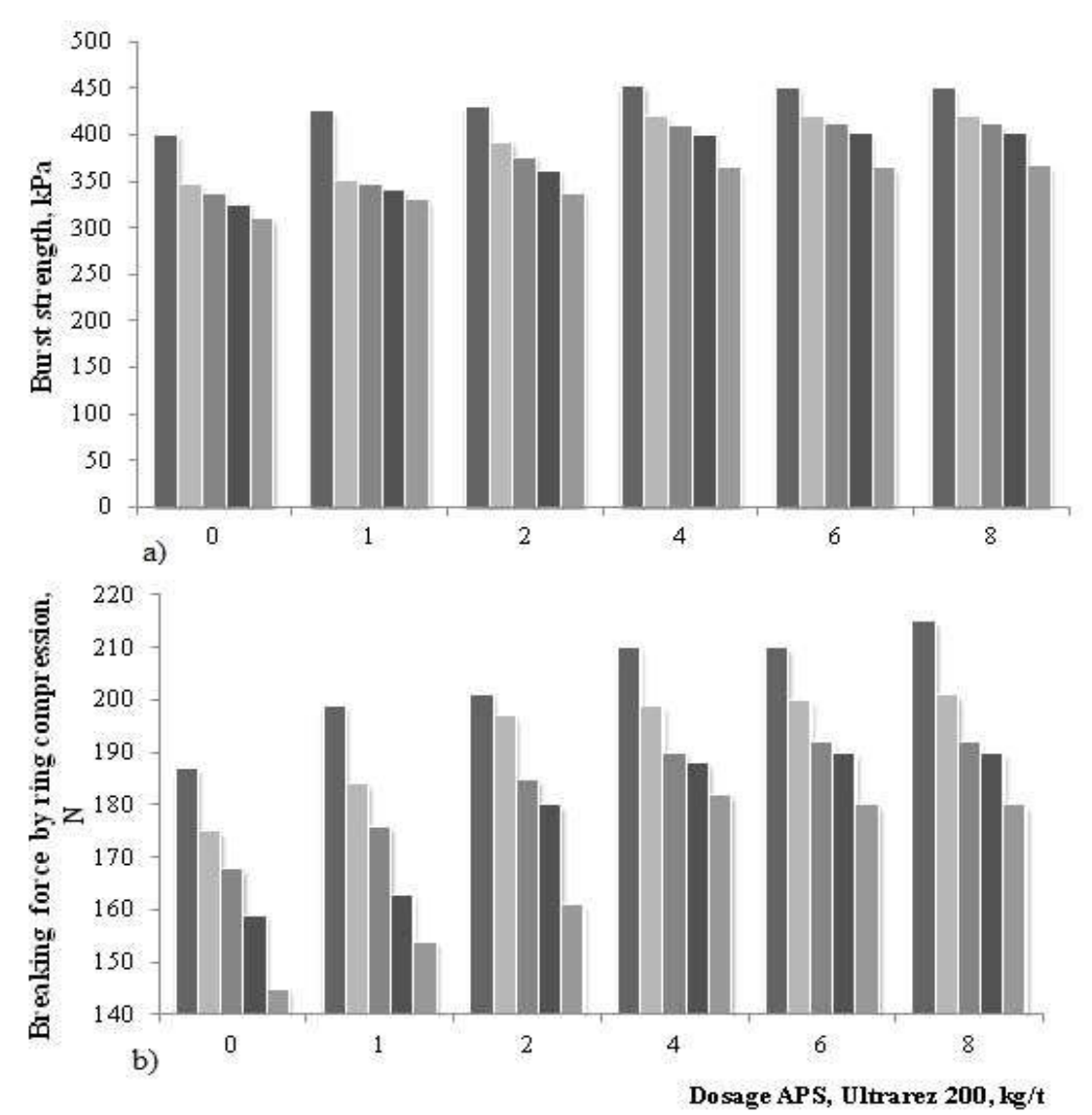

Fig. 4. The diagram of the impact of the APS UltraRes 200 on the burst strength (a) and the breaking force by the ring compression (b) of a cardboard with different composition: $100 \%$ waste paper of group 1; $90 \%$ waste paper of group 1 and $10 \%$ waste paper of group 2; $80 \%$ waste paper of group 1 and $20 \%$ waste paper of group 2; 70\% waste paper of group 1 and $30 \%$ waste paper of group 2; and $100 \%$ waste paper of group 2<smiles></smiles>

Scheme 2

microscopic photos (Fig. 5) indicate that the addition of the APS UltraRes 200 resin to a fibrous composition containing $30 \%$ of waste paper of group 2 results in the re-grouping of short fibers, their convergence and their connection. As a result, a denser structure of a cardboard is formed with the removal of moisture (Fig. 5, d), which is also confirmed by the results of ${ }^{13} \mathrm{C}$ NMR spectroscopy of model solutions and physical-mechanical tests of a cardboard.

\section{Conclusions}

${ }^{13} \mathrm{C}$ NMR spectroscopy was used to study the interaction of the APS UltraRes 200 with sucrose having hydroxyl groups similar to cellulose. The obtained results confirmed the formation of covalent chemical bonds between the APS molecules and cellulose macromolecules due to the transformation of the APS azetidine groups.

It was determined that the maximum efficiency of the APS was achieved at its consumption of $4 \mathrm{~kg}$ 


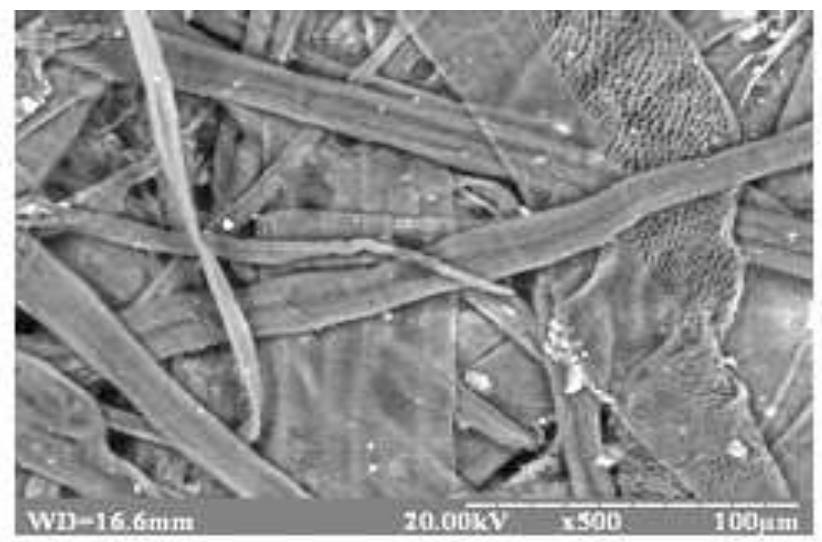

a)

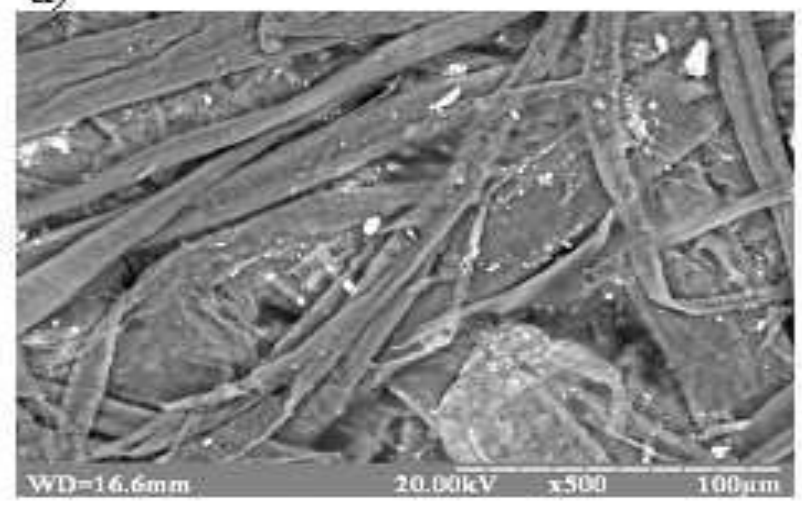

c)

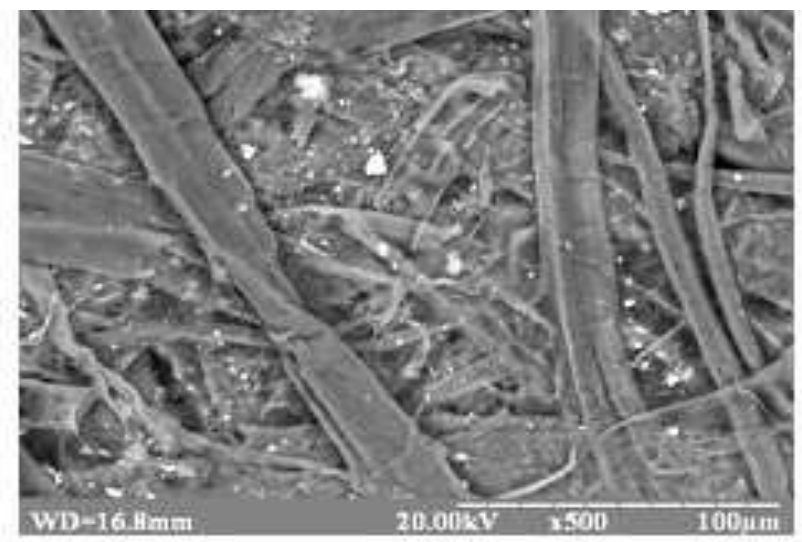

b)

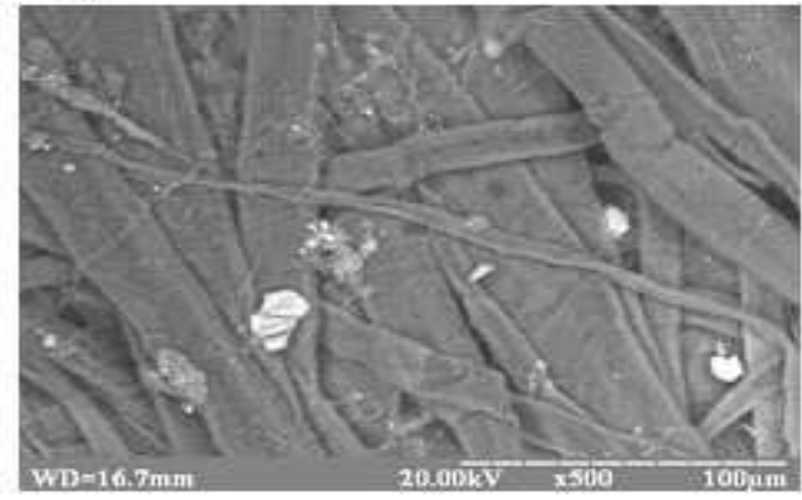

d)

Fig. 5. Microscopic photographs of the samples of a cardboard for flat layers of a corrugated cardboard without (a, b, c) and with the addition (d) of APS UltraRes 200 at its consumption of $4 \mathrm{~kg}$ per ton: (a) - 100\% waste paper of group 1; (b) - 100\% waste paper of group 2; (c) and (d) $-30 \%$ waste paper of group 2 and $70 \%$ waste paper of group 1

per ton and an increase in the content of a shortfiber waste paper in a testliner. It was established that the consumption of APS above $4 \mathrm{~kg}$ per ton is economically inappropriate. The main parameters of the mechanical strength of a cardboard, such as burst strength and breaking force by the ring compression, were increased by $23 \%$ and $18 \%$, respectively, when replacing in a fibrous composition of $30 \%$ of costly waste paper of group 1 by a shortfiber waste paper of group 2. This will eventually reduce the production cost of a testliner.

The microscopic study showed the formation of a denser structure of a cardboard in the case of the consumption of a resin and a short-fiber waste paper in the composition, which was confirmed by the results of physical-mechanical tests of a cardboard.

\section{REFERENCES}

1. Pivnenko K., Eriksson E., Astrup F.T. Waste paper for recycling: overview and identification of potentially critical substances // Waste Manage. - 2015. - Vol.45. - P. 134-142.

2. Yilmaz M. Recycling costs: a research in the waste paper industry // Eur. J. Account. Audit. Financ. Res. - 2015. - Vol.3. - No. 4. - P.58-68.

3. Слаутин Д.В., Теплоухова М.В., Андраковский Р.Э. Повышение прочности бумаги, изготовленной из макулатурной массы // Вестн. Пермского нац. исслед. политехн. ун-та. Хим. технология и биотехнол. -2018. № 1. - C.32-39.

4. Кулешов А.В., Смолин А.С. Влияние цикличности использования макулатурного волокна на бумагообразующие свойства // Лесной журнал. - 2008. - № 4. - С.131-138.

5. Дулькин Д.А., Спиридонов В.А., Комаров В.И. Современное состояние и перспективы использования вторичного волокна из макулатуры в мировой и отечественной индустрии бумаги. - Архангельск: Изд-во АГТУ, 2007. - 1118 c.

6. Hubbe M.A., Venditti R.A., Rojas O.J. What happens to cellulosic fibers during papermaking and recycling? A review // BioResources. - 2007. - Vol.2. - No. 4. - P.739-788.

7. Kang T., Paulapuro H. Recycle potential of externally fibrillated chemical pulp // Progr. Pap. Recycl. - 2006. Vol.15(2). - P.11-17. 
8. The effect of chemical additives on the strength, stiffness and elongation potential of paper / Strand A., Sundberg A., Retulainen E., Salminen K., Oksanen A., Kouko J., Ketola A., Khakalo A., Rojas O. // Nord. Pulp Pap. Res. J. - 2017. Vol.32. - No. 3. - P.325-335.

9. Повышение эффективности технологического процесса производства бумажной продукции из макулатуры путем применения систем удержания-обезвоживания волокна / Глезман Е.А., Житнюк В.А., Ширинкина Е.С., Вайсман Я.И., Белкина Е.В. // Целлюлоза. Бумага. Картон. - 2014. - № 7. - C.62-68.

10. Vishtal A., Retulainen E. Improving the extensibility, wet web and dry strength of paper by addition of agar // Nord. Pulp Pap. Res. J. - 2014. - Vol.29. - P.434-443.

11. Кожевников С.Ю., Ковернинский И.Н. Химия и технология Скиф для бумаги. - Изд-во Московского гос. ун-та леса, 2010. - 91 с.

12. Лук'янова В.В., Остапенко А.А. Екологічні аспекти переробки макулатури з використанням хімічних допоміжних речовин // Екологічна безпека та природокористування. 2017. - № 1-2. - C.78-85.

13. Остапенко А.А., Ковернинский И.Н., Ткаченко О.В. Применение химических вспомогательных веществ для обеспечения ресурсосбережения в производстве бумаги и картона // Химия растительного сырья. - 2018. - № 2. C.225-232. $-160 \mathrm{c}$.

14. Блюмих Б. Основы ЯМР. - М.: Техносфера, 2007.

Received 19.04.2019

\section{ПІДВИЩЕННЯ МІЦНОСТІ ТЕСТЛАЙНЕРА ДОПОМГЖНИМИ ХІМІЧНИМИ РЕЧОВИНАМИ}

\section{А.А. Остапенко, М.Д. Гомеля, О.М. Мовчанюк, І.В. Трембус}

В даній роботі методом ${ }^{13} \mathrm{C}$ ЯМР-спектроскопї̈ здійснені імітаційні досліджсення хімічної взаємодії амфотерної полімерної смоли з иукрозою, що має гідроксильні групи, подібні до целюлозних. Доведено, що в результаті трансформації азетидинових груп амфотерної полімерної смоли утворюються ковалентні хімічні зв'язки між молекулами смоли і гідроксильними групами иукрози. Підтверджено механізм взаємодії амфотерної полімерної смоли з макромолекулами целюлози. Досліджено вплив витрати амфотерної полімерної смоли на фізико-механічні показники тестлайнера різного композиційного складу. Визначено, що зі збільшенням витрати смоли від 1 до 4 кг/m відбувається відчутне зростання показників картону всіх досліджених композицій. Подальще збільшення витрати смоли практично не змінює міцності картону, а тому є економічно недоцільним. Встановлено, що більща ефективність використання амфотерної полімерної смоли досягається за зростання в композиції картону коротковолокнистої фракції. Показано, що за витрати смоли 4 кг/m та за використання в композиції $30 \%$ коротковолокнистої макулатури опір продавлюванню і руйнівне зусилля під час стиснення кільця, що є основними показниками механічної міцності картону, збільшуються на $23 \%$ і $18 \%$ відповідно. Це, в свою чергу, дозволить зменшити собівартість тестлайнера. Здійснено мікроскопічні дослідження зразків тестлайнера різного композиційного складу, шо виготовлені без використання та з додаванням амфотерної полімерної смоли.
Доведено утворення більш щільної структури картону у випадку використання смоли і коротковолокнистої макулатури, що і призводить до зростання міцності картону.

Ключові слова: амфотерна полімерна смола, азетидинові групи, цукроза, целюлоза, ${ }^{13} \mathrm{C}$ ЯМРспектроскопія, макулатура, тестлайнер, фізико-механічні показники.

\section{REINFORCING A TESTLINER WITH SUPPORTING CHEMICAL MATERIALS}

A. Ostapenko *, M. Gomelya, O. Movchaniuk, I. Trembus

National Technical University of Ukraine «Igor Sikorsky Kyiv Polytechnic Institute», Kyiv, Ukraine

\section{* e-mail: alina-ostapenko@ukr.net}

The simulation of the chemical interaction of amphoteric polymer resin with sucrose having hydroxyl groups that are similar to cellulose were carried out using ${ }^{13} \mathrm{C} N M R$ spectroscopy. The transformation of azetidine groups of amphoteric polymer resin proved to result in the formation of covalent chemical bonds between the resin molecules and the hydroxyl groups of sucrose. The mechanism of the interaction of amphoteric polymer resin with cellulose macromolecules was confirmed. The effect of the consumption of amphoteric polymer resin on the physical-mechanical properties of a testliner with different composition was investigated. It was determined that there is a significant increase in the cardboard indices of all studied compositions with an increase in the consumption of resin from 1 to $4 \mathrm{~kg}$ per ton. A further increase in the consumption of resin does not practically change the strength of the cardboard, and hence is economically unreasonable. It was found that a greater efficiency of the use of amphoteric polymer resin is achieved when the content of a short-fiber fraction cardboard in the composition grows. It was shown that the consumption of resin of $4 \mathrm{~kg}$ per ton and the use of $30 \%$ short-fiber waste paper in the composition ensure an increase in the burst resistance and the destructive force during the compression of the ring by $23 \%$ and $18 \%$, respectively; these parameters being the main indicators of mechanical strength of the cardboard. This, in turn, will reduce the cost of a testliner. The samples of a testliner with different composition were examined by the SEM method, the samples were fabricated without and with the addition of amphoteric polymer resin. The formation of a dense structure of a cardboard in the case of the use of resin and short-fiber waste paper was shown, this led to an increase in the strength of cardboard.

Keywords: amphoteric polymer resin; azetidine groups; sucrose; cellulose; ${ }^{13} \mathrm{C}$ NMR spectroscopy; wastepaper; testliner; physical-mechanical properties.

\section{REFERENCES}

1. Pivnenko K., Eriksson E., Astrup T.F. Waste paper for recycling: overview and identification of potentially critical substances. Waste Management, 2015, vol. 45, pp. 134-142.

2. Yilmaz M. Recycling costs: a research in the waste paper industry. European Journal of Accounting, Auditing and Finance Research, 2015, vol. 3, no. 4, pp. 58-68.

3. Slautin D.V., Teplouhova M.V., Andrakovskii R.J. Povyshenie prochnosti bumagi, izgotovlennoi iz makulaturnoi massy [Increasing the strength of paper fabricated from waste paper] Vestnik Permskogo Natsional'nogo Issledovatel'skogo Politehnicheskogo Universiteta. Khimicheskaya Tekhnologiya $i$ Biotekhnologiya, 2018, no. 1, pp. 32-39. (in Russian). 
4. Kuleshov A.V., Smolin A.S. Vliyanie tsiklichnosti ispol'zovaniya makulaturnogo volokna na bumagoobrazuyushchie svoistva [The effect of cyclical use of waste fiber on paper-forming properties]. Lesnoi Zhurnal, 2008, no. 4, pp. 131-138. (in Russian).

5. Dul'kin D.A., Spiridonov V.A., Komarov V.I. Sovremennoe sostoyanie i perspektivy ispol'zovaniya vtorichnogo volokna iz makulatury v mirovoi i otechestvennoi industrii bumagi [The current state and prospects of using recycled fiber from waste paper in the global and domestic paper industry]. AGTU Publishers, Arkhangelsk, 2007, 1118 p. (in Russian).

6. Hubbe M.A., Venditti R.A., Rojas O.J. What happens to cellulosic fibers during papermaking and recycling? A review. BioResources, 2007, vol. 2, no. 4, pp. 739-788.

7. Kang T., Paulapuro H. Recycle potential of externally fibrillated chemical pulp. Progress in Paper Recycling, 2006, vol. 15, pp. 11-17.

8. Strand A., Sundberg A., Retulainen E., Salminen K., Oksanen A., Kouko J., Ketola A., Khakalo A., Rojas O. The effect of chemical additives on the strength, stiffness and elongation potential of paper. Nordic Pulp \& Paper Research Journal, 2017, vol. 32 , pp. $325-335$.

9. Glezman E.A., Zhitnyuk V.A., Shirinkina E.S., Vaisman Ya.I., Belkina E.V. Povyshenie effektivnosti tekhnologicheskogo protsessa proizvodstva bumazhnoi produktsii iz makulatury putem primeneniya sistem uderzhaniyaobezvozhivaniya volokna [Improving the efficiency of the production process of paper products from waste paper through the use of fiber retention-dewatering systems]. Cellyuloza. Bumaga. Karton, 2014, no. 7, pp. 62-68. (in Russian).
10. Vishtal A., Retulainen E. Improving the extensibility, wet web and dry strength of paper by addition of agar. Nordic Pulp \& Paper Research Journal, 2014, vol. 29, pp. 434-443.

11. Kozhevnikov S.Yu., Koverninskii I.N., Khimiya $i$ tekhnologiya Skif dl'ya bumagi [Chemistry and technology Skiff for paper]. Moscow State University Publishers, Moscow, 2010. 91 p. (in Russian).

12. Luk'yanova V.V., Ostapenko A.A. Ekologichni aspekty pererobky makulatury z vykorystannyam khimichnykh dopomizhnykh rechovyn [Aspects of wastepaper recycling using chemical additive agents]. Ekologichna Bezpeka ta Pryrodokorystuvannya, 2017, no. 1-2, pp. 78-85. (in Russian).

13. Ostapenko A.A., Koverninskii I.N., Tkachenko O.V. Primenenie khimicheskikh vspomogatel'nykh veshchestv dl'ya obespecheniya resursosberezheniya $\mathrm{v}$ proizvodstve bumagi $\mathrm{i}$ kartona [Application of chemical additives for resource conservation production of paper and cardboard]. Khimiya Rastitel'nogo Syr'ya, 2018, no. 2, pp. 225-232. (in Russian).

14. Blyumikh B., Osnovy YaMR [Fundamentals of NMR]. Tehnosfera Publishers, Moscow, 2007. 160 p. (in Russian). 